\title{
Geohazards and myths: ancient memories of rapid coastal change in the Asia-Pacific region and their value to future adaptation
}

\author{
Patrick D Nunn
}

\begin{abstract}
Rapid coastal change is common in the Asia-Pacific region yet an understanding of its causes, recurrence times, and impacts is not always clear through the use of conventional geological methods. It is suggested that myths (traditional [oral] tales) are underutilized sources of information about coastal change in this region. This is illustrated by consideration of myths likely to recall (early) Holocene sea-level rise, particularly along the coasts of India and Australia, as well as myths recalling rapid episodic coastal emergence and submergence, the latter including the disappearance of entire landmasses (islands). Two examples of how details in such myths can inform geological understanding of coastal change are given. The first argues that myths recalling the rapid flooding of coastal cities/ lowlands are likely to represent memories of extreme wave events superimposed on a rising (postglacial) sea level. The second suggests that many myths about landmass/island disappearance fail to report the occurrence of rapid (coseismic and aseismic) subsidence even though they provide inferential evidence that this occurred. Few such myths are known to the author from many parts of Asia yet it is likely they exist and could, as elsewhere in the world, help illuminate the understanding of the nature and chronology of rapid coastal change. The challenges involved in helping communities in the Asia-Pacific region adapt to future coastal changes might be partly overcome by the use of appropriate myths to demonstrate precedents and engender local participation in adaptation strategies.
\end{abstract}

Keywords: Asia-Pacific; Myth; Coast; Coastal change; Flooding; India; Australia; Pacific Islands; Tsunami; Subsidence

\section{Introduction}

Coasts in the Asia-Pacific region are sometimes subject to rapid change. Conventional geoscientific methods have commonly been used to understand the causes and recurrence intervals of rapid coastal change but these methods have not always proved adequate to

- identify incidences of occasional (low-frequency) rapid (often high-magnitude) change because the evidence for these is obscured by later coastal changes, and

- understand how rapid coastal changes impacted coastal societies and ecosystems at particular times.
The most common types of rapid change are those associated with the impact of large waves, be they storm surges or tsunamis, that may alter both the position and nature of the shoreline. Yet these types of change are often also reversible because they are not generally associated with long-term changes in level of either the land or sea surface. Exceptions to this occur when large-wave impacts are superimposed repeatedly on gradual (monotonic) changes in sea level or when a tsunamigenic ocean-floor earthquake causes a nearby coastline (land and/or ocean floor) to rise or fall rapidly [1,2].

Other types of rapid change also periodically affect some Asia-Pacific coasts, especially those in tectonically unstable areas. Shallow-focus thrust earthquakes, which are comparatively frequent along many plate boundaries in the region, sometimes cause rapid coseismic uplift or subsidence [3,4]. The effects of these earthquakes are often most noticeable along coasts where shallow sea 
floor emerges rapidly or where coastal lowland fringes are abruptly submerged. In addition, collapses of (steep) slopes along coastlines, both above and below sea level, often lead to rapid land submergence. Such collapses may be triggered by earthquakes or volcanism, sometimes solely by gravity.

For all these types of rapid coastal change, there is interest in knowing how often (frequency) and how much (magnitude) they affect particular Asia-Pacific coasts, not least to understand the effects they might have should they re-occur in the future [5]. Reliable data on the frequency of past instances of rapid coastal change are difficult to obtain, often because long-term (background) change is not monotonic but also because data are often difficult to isolate and interpret because of the effects of other processes contributing to coastal evolution over the time periods involved.

The largely unacknowledged source of data about rapid coastline change in the Asia-Pacific region on which this paper focuses is myth, the traditional (oral) tales that are characteristic of many of the unique cultures in this region [6-9]. Some such myths - termed euhemeristic - derive from observations of natural phenomena by pre-literate people who encoded their experience in memorable stories, passed down orally through subsequent generations. Such myths have the potential to provide additional information around the nexus of geological and historical sources of information about geohazards (Figure 1). Some such myths also have considerable potential for identifying instances of rapid coastal changes in the past and can therefore be used to illuminate the nature and chronology of rapid coastal change in both the past and, by analogy, in the future.

\section{Review: euhemeristic myths referring to coastal change in the Asia-Pacific region}

It is only in the last few decades that geoscientists have begun to appreciate the potential value of (euhemeristic) myths for an understanding of a range of geological phenomena $[10,11]$ yet hardly any of the most influential case studies come from the Asia-Pacific region (Figure 2). Exceptions are associated mostly with certain Pacific Island groups and with New Zealand and Australia where myths were transcribed in the earliest parts of their literate histories $[6,12]$. Another significant difference is that in many parts of the Asia-Pacific region, because culture has not always been considered to be rigidly separate from science, myths were not excluded from developments in the understanding of natural phenomena in the way that they were in many other parts of the world [13].

This paper deals with myths referring only to (apparently) rapid coastal change, which is described under three headings - long-term (slow, monotonic) coastal change punctuated with instances of extreme change; rapid coastal emergence; rapid coastal submergence. Following these descriptive sections, the value of an approach to coastal change incorporating myth is explained and illustrated in two ways - one where it is argued that many myths recalling apparently rapid coastal submergence may in fact be more plausibly interpreted as recalling the superimposition of recurring extreme events on a slowly rising sea level; the other where it is argued that myths supply evidence for rapid subsidence during particular events that has not been gleaned by geoscientists in any other way.

\section{Myths suggesting long-term coastal change}

Short-lived, often largely reversible, coastal changes are common along Asia-Pacific coasts as they are elsewhere. Tropical cyclones (typhoons) affect an increasing number of tropical coasts in the region [14], often resulting in major changes to the superficial geology of the coastal zone, particularly where there are no offshore reef barriers to offset the impacts of storm surges [15]. Tsunamis, which potentially affect most Asia-Pacific coasts, can cause far greater changes to coastal environments than storm surges.

It is possible that myths referring to coastal submergence (drowning) in the Asia-Pacific developed several thousand years ago during the early Holocene, perhaps late Pleistocene, in response to the inundation of the Sahul and Sunda shelves by postglacial sea-level rise. At least one serious writer has claimed that evidence for supporting the interpretation of these as euhemeristic myths, and their subsequent outwards dispersal, is today found in various forms of land-raiser myths in cultures across the entire region, from India in the west to the Pacific Islands in the east [7], a suggestion that has found some support from archaeology [16] and subregional myth analyses $[17,18]$.

Along the coast of India, there are numerous myths that plausibly also refer to long-term (postglacial) coastal change (Figure 3). A long history of significant coastal settlement in northwest India, particularly along the Saurashtra coast (Gujarat), has led to a wealth of information about shoreline change that became encoded in myth. In the Mahabharata, the ancient (golden) city of Dwaraka was once the abode of Lord Krishna who left it shortly before it was inundated by the ocean and abandoned. Long regarded as a probable fiction, archaeological investigations have found a wealth of evidence to support the existence of Dwaraka as well as numerous other coastal settlements nearby that were probably also rendered uninhabitable as a result of coastal change during the Harappan period, more than 3000 years ago $[19,20]$. Tectonic changes and associated tsunami may have contributed to the abandonment of Saurashtra coastal settlements like Dwaraka [21] although it is likely that (postglacial) sea-level rise played a more prolonged role in this. 

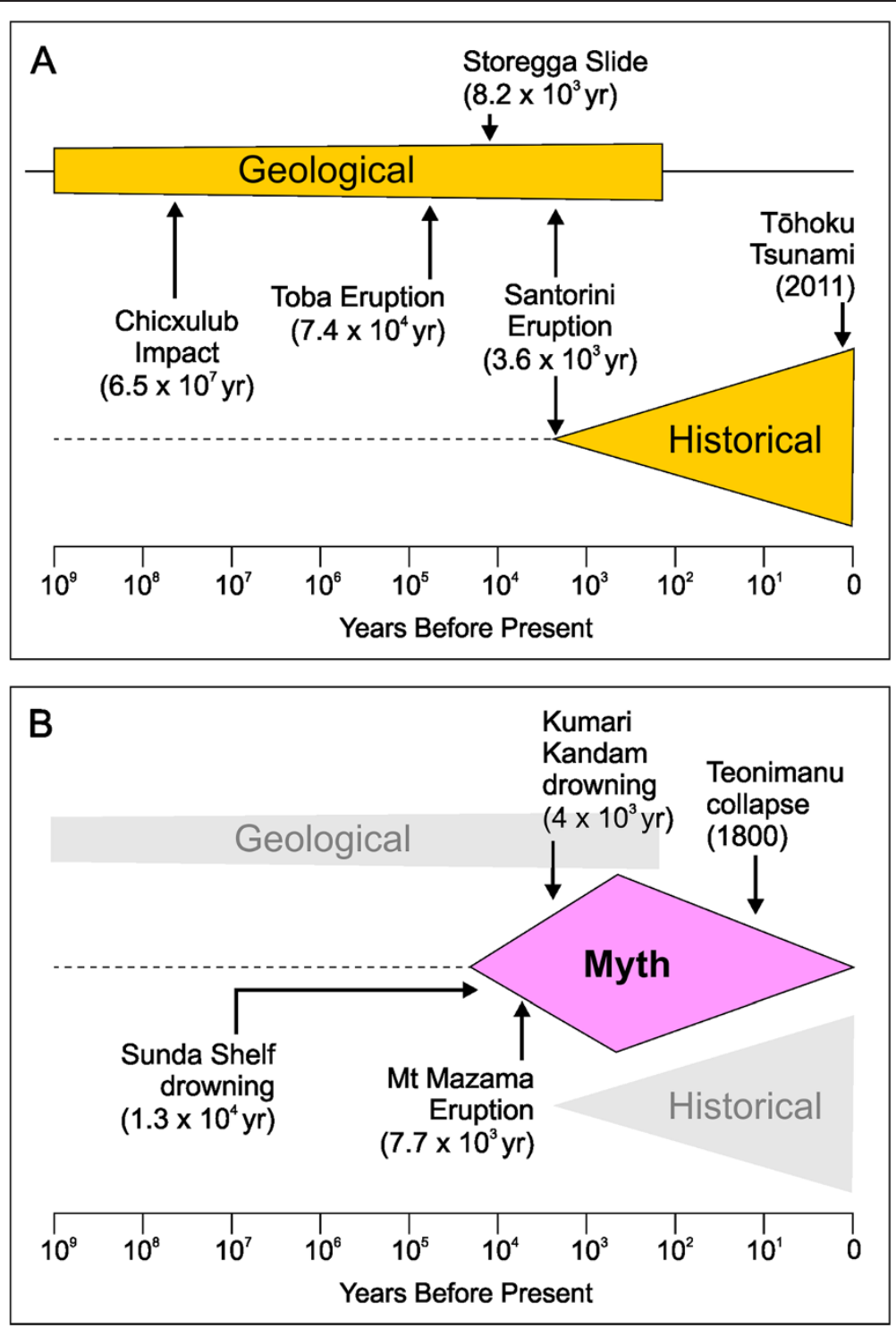

Figure 1 The potential of myths to provide information that spans geological and historical sources of information about past geohazards. The vertical scale is an approximation of amount of precise information about geohazards at particular times in the past. A: Examples of geohazards about which information has been acquired from geological and historical sources. B: Examples of how information from myths can be used to supply details about geohazards, particularly in the period where only limited information is available from geological or historical sources.

On the east coast of India are found myths relating to submergence of ancient port cities and their most memorable components, particularly temples [22]. Near the mouth of the Kaveri River exist the remains of the ports of Poompuhar and Tranquebar. The Manimekhalai, a Tamil epic, describes how the port city of Poompuhar was destroyed by an angry goddess in a flood and much archaeological evidence has been found to support details contained in the myth [23]. While most such traditions are ancient, probably at least 2000 years old, some are more recent and point to continued shoreline change in the last few hundred years. Of these, the most compelling is the description on a $17^{\text {th }}$-century Dutch chart of the 'seven pagodas' of Mahabalipuram, six of which are said in myths to have been submerged in a single day long ago [24].

In southern India, Tamil myths contain many allusions to ancient lands now underwater. Some myths refer to the drowning of the former cities of Madurai (Maturai) and Kapatapuram and recall that "the sea swallowed up forty-nine provinces of ... land from the Pahruli River to the north bank of the Kumari River' ([25]: 294). Some Tamil traditions refer to the existence of Kumari Kandam, an ancient land (now 


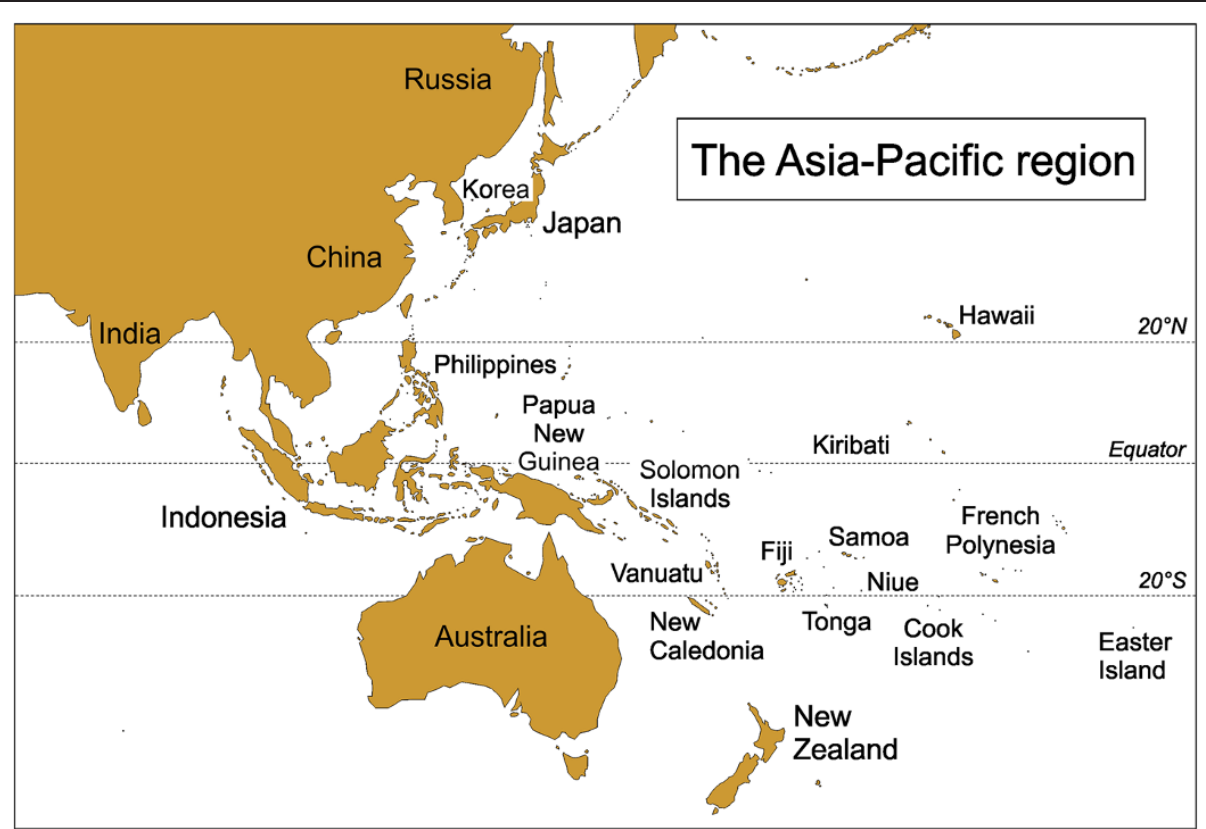

Figure 2 Map of the Asia-Pacific region showing the main places mentioned in the text.

submerged) off the coast of southernmost India where Tamil culture reputedly originated, a tradition that informed more recent global legends about the 'lost continent' of Lemuria in the Indian Ocean [26].
Another well-known myth found in the Mahabharata, perhaps around 4000 years old [27], tells of the bridge that was constructed by the monkey army of Lord Rama in order for them to reach Sri Lanka from the coast of southeast India and rescue his consort who had been

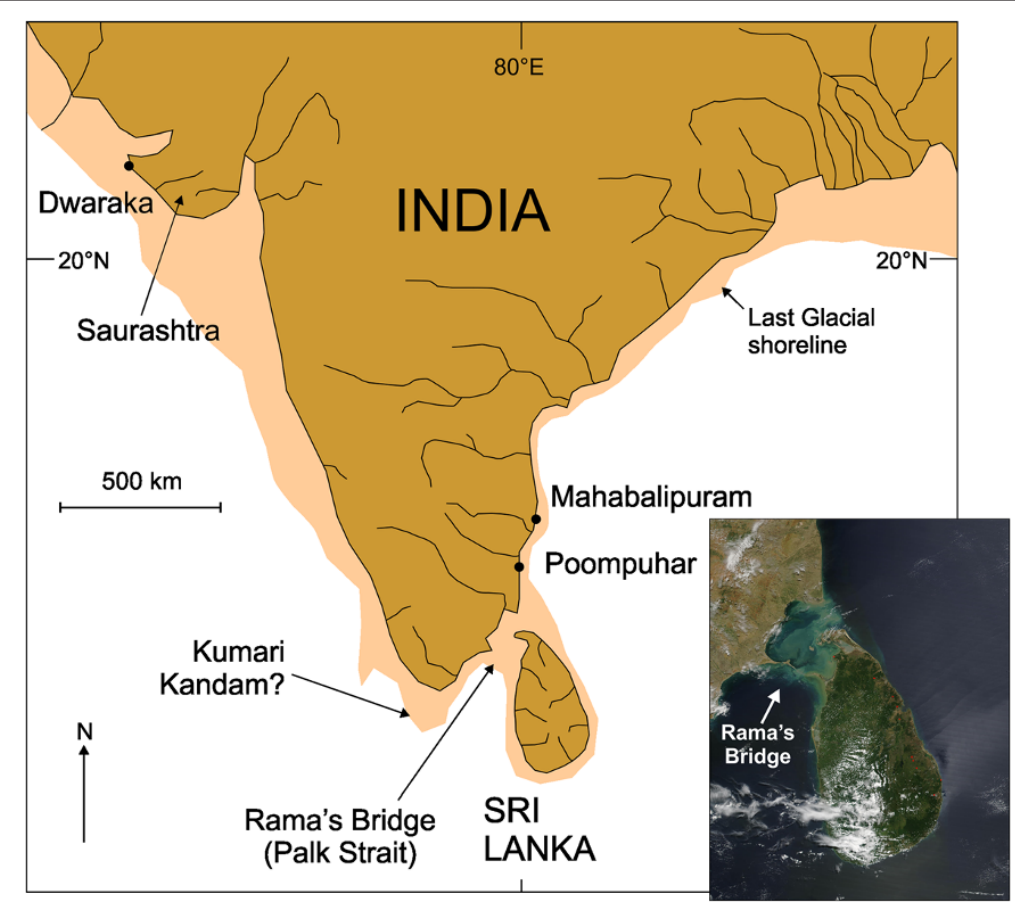

Figure 3 The coast of India and Sri Lanka showing the extent of the shoreline at the Last Glacial Maximum (from topex.ucsd.edu/ marine_topo/mar_topo.html) and places mentioned in the text. Inset shows a satellite image of Rama's Bridge (Credit: Jacques Descloitres, MODIS Land Rapid Response Team, NASA/GSFC). 
kidnapped. Rama's Bridge is now regarded by scientists as a natural formation, built of reef and/or beachrock, that was emergent across the modern ocean gap (Palk Strait) some time before 4500 BP when sea level was lower than today [28]. Rama's Bridge is detectable on satellite images (Figure 3, inset).

Comparable myths to those from India come from parts of the coast of Australia (Figure 4), where Aboriginal people amassed a series of traditions over at least the last 40,000 years. Some of these traditions refer to rapid coastal change and plausibly represent the overtopping by the ocean of a coastal shelf or the breaching of a coastal barrier (as postglacial sea level rose) leading to the abrupt inundation of an area of lowland. A good example comes from Port Phillip Bay at the head of which the modern city of Melbourne now lies. Several Aboriginal myths provide explanations for the drowning of this bay, recalling that it had previously been dry land and a place where emus and kangaroos were hunted $[29,30]$.

Similar evidence was collected from Aboriginal tribes in other parts of Australia [31,32]. For example, off the coast of western Australia (Figure 4, left inset), there is a tradition that "Rottnest, Carnac, and Garden Island, once formed part of the mainland, and that the intervening ground was thickly covered with trees" ([33]: Dictionary, $\mathrm{p} 8$ ). On the east coast, an equivalent tradition states that it was once "possible to walk across to the islands" offshore ([34]: 29), namely Hinchinbrook and Palm islands (Figure 4, right inset).

Given that people have been living on Pacific islands for only the past 3000 years or so [35], slightly after the time of the Holocene sea-level maximum in this region [36], it is no surprise that, despite the formidable body of oral traditions that exist there [6,37], there are none that plausibly recall slow, enduring sea-level rise as there are in India and Australia. It is expected that there would be such oral traditions in East Asia although none are known to the author.

\section{Myths recalling rapid coastal emergence}

Many parts of the Asia-Pacific coast are periodically subject to rapid emergence as a result of (coseismic) uplift during an earthquake [4]. While the uplift magnitude may be subsequently reduced in magnitude by subsequent (interseismic) subsidence, the net long-term effect is usually coastal emergence. Myths that plausibly recall incidences of rapid coastal emergence are found in the Pacific Islands region, where there are many island coasts that have been subject to regular such events within the time of human occupation of particular islands $[38,39]$.

Examples come from the islands of Tonga and nearby Niue Island, where successive rapid uplifts of islands are encoded in myths that talk of gods stamping repeatedly

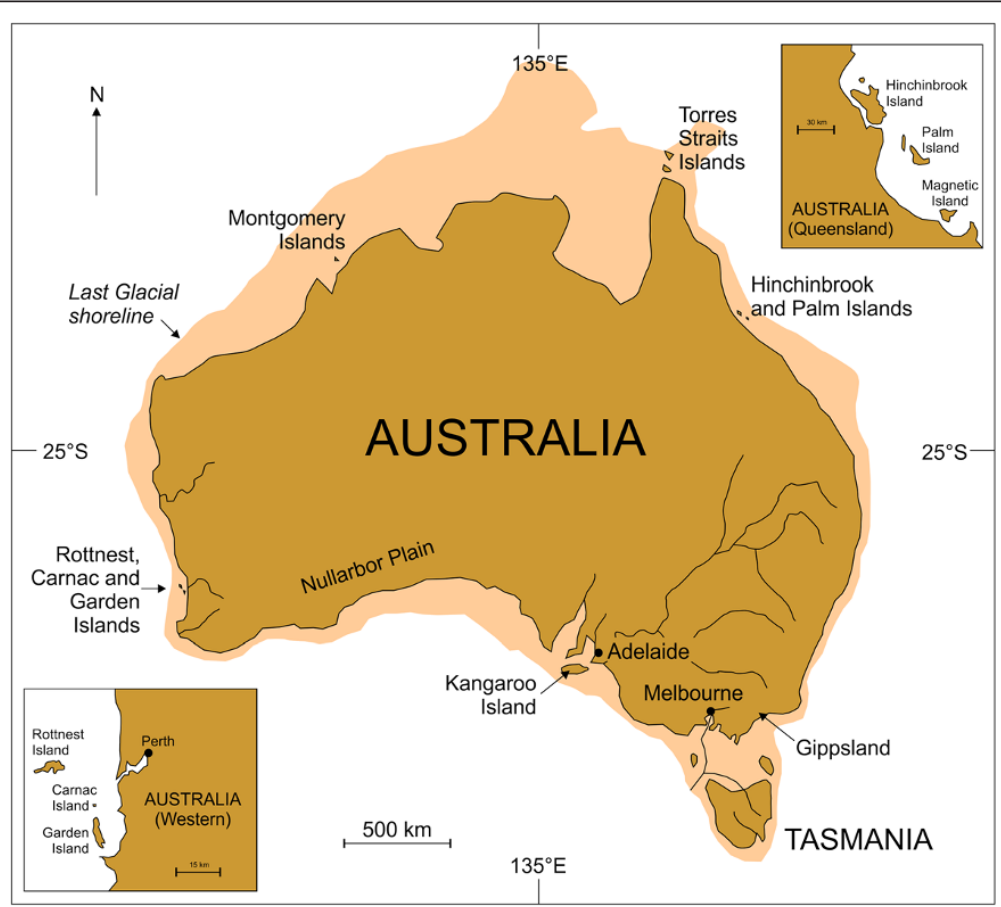

Figure 4 The coast of Australia showing the extent of the shoreline at the Last Glacial Maximum (from topex.ucsd.edu/marine_topo/ mar_topo.html) and places mentioned in the text. Insets show details of selected sites. 
on the ground surface causing it to rise $[40,41]$. One myth from Niue refers to a time before an island existed; the demi-god "Maui was in a cave on the sea floor and pushed it up until Niue became 'a reef awash at low water'; with another heave, Maui 'sent it higher than the spray can reach ... and it became an [high limestone] island like to Tonga" ([42]: 85-86).

It is likely that other myth motifs in the region, particularly that from the Pacific about islands being fished-up from beneath the ocean surface [18], have incorporated observations about rapid (coseismic) uplift in various places. It might be expected that similar myths exist amongst cultural groups in Indonesia, Japan and Papua New Guinea, where coseismic uplift affects some coasts [4], although no such myths are known to the author.

\section{Myths recalling rapid coastal submergence}

While coseismic subsidence is known to have affected Asia-Pacific coasts, it is less common than coseismic uplift. Certain myths about islands that sank abruptly in western Pacific Island groups [43,44] contain elements consistent with rapid subsidence but are generally dominated by details concerning the (tsunami) waves that reportedly overran particular islands. Coseismic subsidence may be implicated in the destruction of Luondona-Wietrili Island (Timor) after myths tell how it (and the coasts of nearby islands) was repeatedly lashed by a giant sailfish (van Engelenhoven in [7]). A similar myth explains how the island of Fatu Huku (Marquesas, French Polynesia) was largely destroyed [45], something that may have happened only within the past 200 years [46].

Myths that involve islands or coasts being cut or chopped, commonly by a giant being wielding a giant tool, are common in many parts of the Asia-Pacific region and may recall times when large coastal landslides occurred, perhaps triggered by a large-magnitude earthquake. Island-cutting myths are common in parts of Indonesia; the god Atuf is said to have made Borneo into the island it is today by severing its connections with other islands using a giant spear [7]. The Shimane Peninsula (western Honshu, Japan) is said to have been formed when a giant plough was used to slice the land [17] while Meru Mountain, after it was shifted to eastern Java (Indonesia), was trimmed to give it its present shape [47]. On Easter Island (southeast Pacific Ocean), the god named Uoke is said to have to prised pieces off the volcanic cliffs with a giant crowbar until it broke on the hard rocks at Puko Puhipuhi [48]. Hawaiian myths tell of a goddess named Hi'iaka dismembering the body of a dragon-like creature to create coastal lowlands on O'ahu Island, a story that has been reconciled with geoarchaeological evidence [49].
The most extreme example of coastal submergence is when an entire landmass (usually an island) is said to have vanished, something that is quite common in myths but has only recently become regarded as a credible geological phenomenon [41,50]. Among the betterdocumented examples from the Asia-Pacific region are the myths about the disappearance of the islands of Burotu (Fiji Islands) and Teonimanu (Solomon Islands).

Stories about the legendary island Burotu (Pulotu) are widespread among people in the island groups of Fiji, Samoa, Tonga and elsewhere and appear to point to either the island Matuku (southeast Fiji) or one nearby that has disappeared [51]. Details that position this vanished island off the southwest coast of Matuku and involve its periodic reappearance could be interpreted as meaning that Burotu existed within the last 3000 years that this part of the Pacific has been inhabited and perhaps disappeared as a result of a flank collapse of the steep-sided Matuku Volcano (Figure 5).

While Burotu may have disappeared more than 2000 years ago, the available chronological data suggest that Teonimanu disappeared between the years 1568 and 1773, perhaps fewer than 300 years ago, and that it did so as a result of an earthquake-triggered collapse of the steep subterranean slope of the adjoining Cape Johnson Trench (Figure 6). Many stories about Teonimanu collected from the inhabitants of surrounding islands link its disappearance to ground tremors, noise and smoke coming from beneath the ocean surface, and a tsunami train (perhaps eight waves), all of which imply that seismic-triggered collapse of undersea slopes were involved in island disappearance $[41,44]$. Seismic refraction data suggest that there have been multiple collapses along the sides of the Cape Johnson Trench [52,53] which makes this interpretation of the myths surrounding the disappearance of Teonimanu more credible.

\section{Interrogating the details of coastal change myths}

In several instances, the details in myths have been used by geoscientists to better understand a particular phenomenon. This is truest of volcanoes, particularly in reconstructing their eruptive histories in times before written observations began to be made. The active/dormant volcanoes of Mt Mazama (Oregon, USA) and Santorini (eastern Mediterranean) are good examples of this [11], as in the Asia-Pacific region is Mt Fuji (Honshu Island, Japan) and the volcano of Nabukelevu (Kadavu Island, Fiji). In the latter case, myths about an eruption of Nabukelevu within the past 3000 years were adjudged implausible [56] until subsequent research, based on newly-exposed sections through the volcano flanks, revealed this had in fact been the case [57]. In a converse situation, Maori myths interpreted as meaning that the last eruption of Rangitoto Volcano (North Island, New Zealand) 


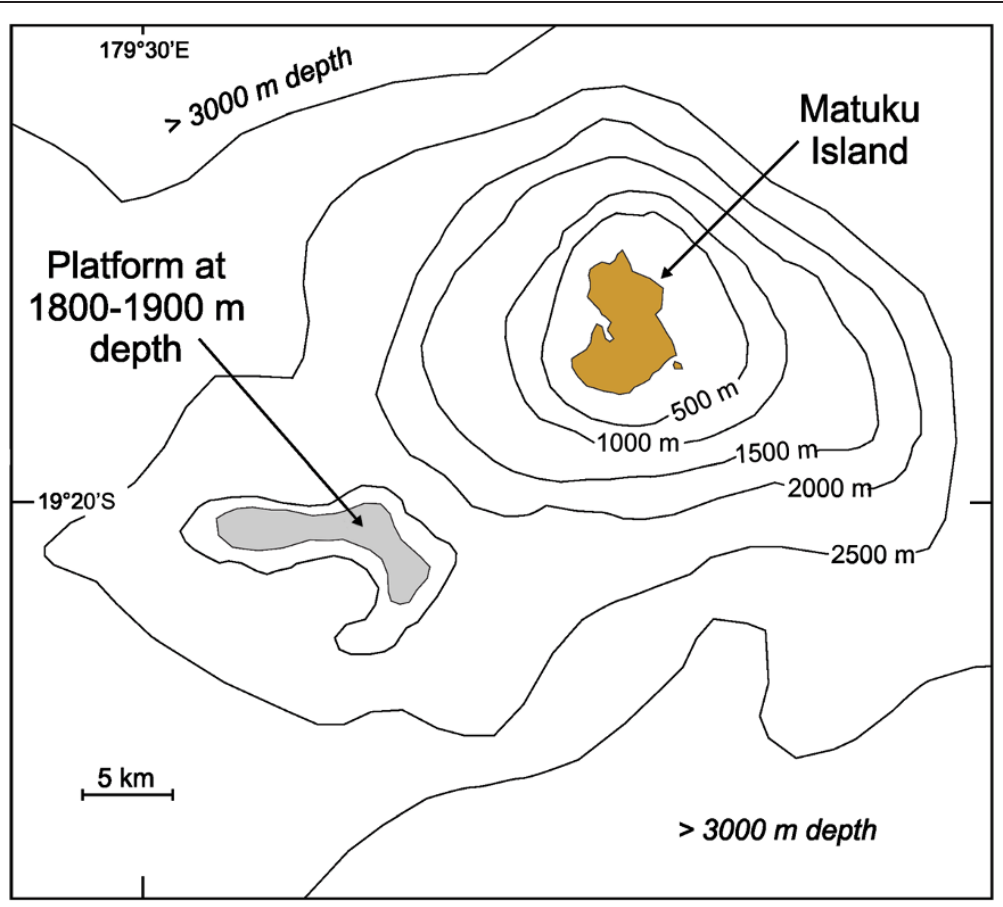

Figure 5 Bathymetry around the island of Matuku (southeast Fiji) showing a submarine platform at $-1800-1900 \mathrm{~m}$ that might have formerly been emergent, the source of myths about the island of Burotu in this part of the Pacific (after [41]).

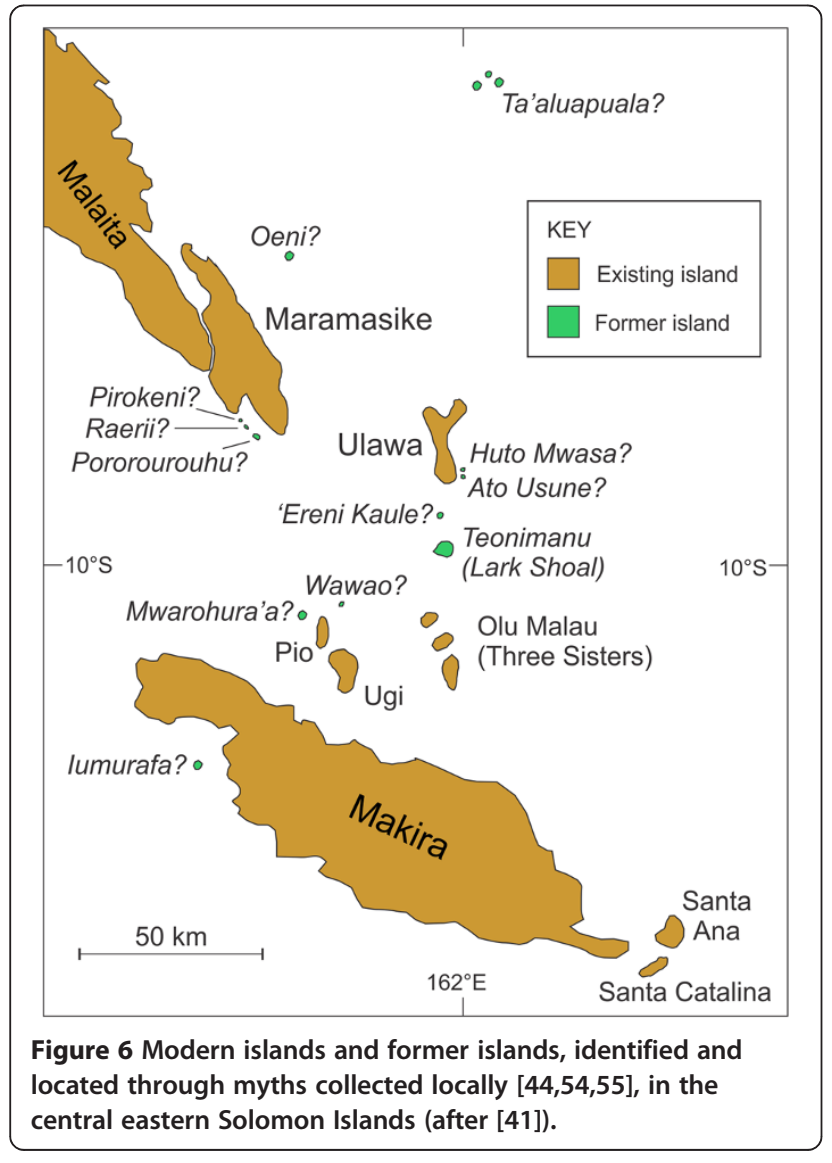

occurred about AD 1400 have been borne out by scientific data despite popular suggestions of more recent activity [58].

In this section, two aspects of comparatively common coastal-change myths from the Asia-Pacific region are interrogated and their likely implications for the understanding of particular phenomena are deduced. The first refers to how myths that recall apparent abrupt coastal flooding leading to permanent coastal change are in fact likely to be expressions of the superimposition of extreme wave events on a rising sea level, while the second focuses on why many myths about island disappearance fail to mention rapid subsidence even though this is implied by the position of these underwater islands today.

\section{Myths recalling abrupt coastal flooding}

Today the most visible and enduring effects of storm surges and tsunamis on Asia-Pacific coasts are often on their inhabitants and infrastructure yet the impacts on coastal geology and vegetation are also often profound. In terms of superficial geology, while erosion and aggradation may both result from large-wave impacts $[59,60]$, it is clear that the coastline can often return to its original condition so that the net (long-term) impact of these events is almost negligible; in systems language, this concept is that of an intransitive coastal system, in which boundary conditions do not change, perturbed by an abrupt (wave impact) event [61]. Exceptions to this occur when extreme events of this kind are superimposed 
on natural coastal systems that are already changing monotonically as a result of long-term forcing, typically involving either sea-level rise or sea-level fall: an example of a transitive system. In such cases, it would be expected the effect of large-wave impact events (storm surge or tsunami) would change through time and that long-term equilibrium would never be restored. For example, where storm surges associated with tropical cyclones are imposed on a rising sea level, as in the Bay of Bengal over recent decades, their inland reach will in time become greater and impacts consequently progressively more extensive [62].

For people in earlier (often pre-literate) times, the most noticeable effects of such transitive changes in coastal systems may have been the cumulative effects of successive extreme (wave) events resulting from long-term changes in system boundary conditions, an analogous situation to the effects of extremes on rising $21^{\text {st }}$-century sea level [63]. This may have entailed, for example, punctuated retreat or advance of the shoreline under conditions of rising or falling sea level respectively. Myth-encoded observations of coastal change and associated submergence of many parts of the coast of the Indian sub-continent are preserved in various ancient texts like the Mahabharata and the Ramayana. They commonly report the 'impact' of a 'giant wave' that engulfed a coastal city leading to its 'destruction', the death of many of its inhabitants and (implicitly) its subsequent abandonment; good examples come from myths about the coastal cities of Dwaraka, Mahabalipuram and Poompuhar, which are known to have once existed $[20,64]$, together with those whose existence may be allegorical like the city of "Maturai which was flooded by the sea" ([25]: 294) and Tonipuram, the city of the boat [25].

It seems unlikely that a single such event would have produced such lasting effects unless it was superimposed on a period of prolonged sea-level rise, such as occurred around the coast of India during the early Holocene, perhaps 7300-4900 cal BP $[65,66]$. In this interpretation, the event would have been a recurring extreme, perhaps a storm surge or a tsunami, but being superimposed on a rising sea level would have had effects unsurpassed in the memories of the affected people and may consequently have led to the abandonment of the city in question. Since many of these cities already had coastal defences - plausibly a response to previous shoreline erosion and extreme wave events - these would have quickly fallen into disrepair, hastening the 'disappearance' of the city and its change from a real to a mythical place. Such a scenario seems applicable to Dwaraka, both the reality and the location of which were uncertain until investigations in the 1980s [67], and to Mahabalipuram about which myths were abruptly validated following the exposure of part of the ancient city by tsunami waves generated by the 2004 Indian Ocean Earthquake [24].
The coastal-change myths from Australian Aboriginal informants are most plausibly explained as a consequence of inundation by rising postglacial sea level of low-lying areas, either connecting the mainland with an offshore island or separated by a coastal barrier from the deep ocean. While extreme events may be implicated in some of the myths, in most cases these can be adequately explained by sea level rising over the edge of a low-lying coastal plain and flooding it with unprecedented rapidity. From the Melbourne area (see Figure 4), there are various myths that recall the sea 'breaking in' (Hull in [30]), perhaps during "a hurricane - trees bending to and fro - then the earth sank, and the sea rushed in ... till the void places became broad and deep, as they are today" (McCrae in [29]: 33). It is likely that the details about extreme winds, earth sinking, and 'filling' of these coastal shelves being rapid are all embellishments added to the simple yet otherwise transgenerationally unmemorable observation of the slowly rising ocean spilling onto a coastal shelf.

\section{Myths ignoring subsidence}

As in other regions, abrupt subsidence during (or immediately after) earthquakes is something that is common in parts of the Asia-Pacific region yet which is not always easy to detect in pre-monitoring records [68,69]. And while intuitively we might not expect it to be so, abrupt subsidence at coastal locations is also something that is frequently ignored in myths, usually because observers of these events focus on the large waves that accompany them. This appears true of many such events in ancient Greece [70] as well as the memorable 1755 Lisbon Earthquake [71]. In some myths from the AsiaPacific region, there is clear evidence that rapid subsidence affected a particular (former) island even though the myths claim that it was only the accompanying (tsunami) waves that caused it to disappear.

A good example is Teonimanu (see Figure 6), the modern location of which is claimed by local people to be marked by Lark Shoal $[44,54,55]$. Assuming this is correct, then given that the surface of Lark Shoal is presently $9 \mathrm{~m}$ below mean sea level, this suggests that, if the island it was once stood above mean high-water level (as it must have been as it was inhabited), then it has subsided at least a net $12 \mathrm{~m}$ or so since this time. In some reports, Teonimanu was a high (bedrock) island, so $12 \mathrm{~m}$ represents a minimum figure for subsidence. But more importantly, none of the myths about the disappearance of Teonimanu mention subsidence, only the impact of successive large waves which are claimed in one account to have run across the island until it was "totally submerged" ([41]: 203).

Other examples come from the islands of Vanuatu where a number of traditions speak of islands that have disappeared yet whose former locations are well known 
and marked by shoals [43]. These include the islands of Malveveng and Tolamp, both off the northeast coast of Malakula Island. The surface of Malveveng is $4-5 \mathrm{~m}$ below mean sea level, that of Tolamp is deeper, around $15 \mathrm{~m}$ below sea level. Evidence that they disappeared as the myths imply is supported by the fact that there are many similar submerged island-type structures visible on the steep submarine slopes leading from the coast of Malakula into the adjoining South Aoba Basin [72].

All these former islands - Teonimanu, Malveveng and Tolamp - were reportedly inhabited, which is why their abrupt disappearance is so memorable in the oral traditions of the present inhabitants of nearby islands, and some accounts suggest they were bedrock islands (not of superficial composition) and reached more than $5 \mathrm{~m}$ above high-tide level [43]. All myths about their disappearance mention large waves and the likeliest interpretation of why these islands vanished is that an earthquake (series) triggered sea-floor collapse and associated island (coseismic) subsidence and (aseismic) slip which together caused the island to disappear beneath the ocean surface. Survivors of all these events are known in the myths, so it is likely that some inhabitants of the affected islands had enough time to escape, suggesting that coseismic subsidence may have been followed by slower aseismic subsidence before the entire island became submerged. Although it is impossible to calculate the contributions of coseismic and aseismic subsidence to the particular instances of island disappearance, it is likely that the latter was greater, given that maximum magnitudes of observed coseismic subsidence in most such geotectonic situations are only around $1 \mathrm{~m}[73,74]$.

\section{Conclusions}

In the Asia-Pacific region, many extant myths belonging to peoples occupying coasts that are periodically subject to major geological change have value in reconstructing the recurrence of such changes and in planning for the future of such places. In this paper, myths concerning rapid coastal change have been examined. These myths represent a body of indigenous knowledge that can help in developing adaptive strategies for future coastal change $[75,76]$; much the same has been demonstrated for myths derived from observations of volcanic activity $[77,78]$.

Although gaining increased acceptance in the past decade, this view that (euhemeristic) myths can contain information about past observations of environmental (and societal) change is still regarded as somewhat controversial by many social scientists. It is more difficult to gauge the view of geoscientists concerning the potential for oral traditions to inform the understanding of geological phenomena, although recent trends suggest a growing receptiveness to the idea [10]. The key seems to be a need to accept that stories which evolved from 'cultural milieux' different from those in which an individual was raised may appear ephemeral and without scientific meaning but a proper judgement on that cannot readily be made by such an individual [79].

To this end, in keeping with trends elsewhere in the world, it would seem important for geoscientists intimate with Asia-Pacific cultures to help gather and identify myths that might inform our understanding of past coastal change in this region and, through an understanding of past effects on environments and societies, contribute to the management of expected future coastal changes. This is becoming a huge challenge, not because science cannot identify plausible futures for environments and peoples in the Asia-Pacific region but because of the difficulties in persuading regional decision-makers at every level (including community level) to support adaptive strategies that invariably fail to acknowledge local cultural values.

This issue has proved problematic in the implementation of community responses to volcanism [80] and to the impacts of associated hazards [81,82]. In terms of responding to future sea-level rise, particularly changes in extremes superimposed on long-term sea-level rise over the next few decades [83], there is a growing need for decision-makers in the Asia-Pacific region, particularly in its poorer countries, to implement effective and sustainable adaptation strategies to ensure livelihood sustainability $[84,85]$. The incorporation of local traditions, such as myths recalling precedents in particular areas, could make a significant difference to the degree of community acceptance of adaptation strategies $[75,76]$, particularly as the disruption of human livelihoods along Asia-Pacific coasts becomes more widespread as sea level rises over the next few decades and beyond [83].

\section{Competing interests}

The author declares he has no competing interests.

\section{Acknowledgements}

This paper is based on part of a Distinguished Lecture I gave at the $10^{\text {th }}$ Annual Meeting of the Asia Oceania Geosciences Society (AOGS) in June 2013. I am grateful to Professor Kenji Satake and the AOGS Council for this honour.

Received: 3 September 2013 Accepted: 15 November 2013 Published: 6 March 2014

\section{References}

1. Wang Z, Zhan Q, Long H, Saito Y, Gao X, Wu X, Li L, Zhao Y (2013) Early to mid-Holocene rapid sea-level rise and coastal response on the southern Yangtze delta plain, China. J Quat Sci 28(7):659-672

2. Woodroffe CD (2002) Coasts: Form, Process and Evolution. Cambridge University Press, Cambridge

3. Niwa Y (2012) Coseismic subsidence recorded in the Holocene delta sequence of the Nobi plain at the footwall side of the Yoro fault. Quat Int 279:353 
4. Ota Y, Yamaguchi M (2004) Holocene coastal uplift in the western Pacific Rim in the context of late quaternary uplift. Quat Int 120(1):105-117

5. Switzer AD, Sloss CR, Horton BP, Zong Y (2012) Preparing for coastal change. Quat Sci Rev 54:1-3

6. Knappert J (1992) Pacific Mythology. Aquarian Press, London

7. Oppenheimer S (1998) Eden in the east: the drowned continent of Southeast Asia. Weidenfeld and Nicolson, London

8. Ramaswamy S (2000) History at land's end: lemuria in tamil spatial fables. J Asian Stud 59(03):575-602

9. Storm R (2003) Mythology of Asia and the Far East: Myths and Legends of China. Southwater, Japan, Thailand, Malaysia and Indonesia, London

10. Piccardi L, Masse WB (2007) Myth and Geology. Geological Society of London, London

11. Vitaliano D (1973) Legends of the Earth: their Geologic Origins. Indiana University Press, Bloomington, Indiana

12. Berndt CH, Berndt RM (1994) The Speaking Land: Myth and Story in Aboriginal Australia. Inner Traditions/Bear \& Co, Rochester, Vermont

13. Masse WB, Barber EW, Piccardi L, Barber PT (2007) Exploring the Nature of Myth and its Role in Science. In: Piccardi L, Masse WB (eds) Myth and Geology. Geological Society of London, London

14. Wu L, Wang B, Geng S (2005) Growing typhoon influence on east Asia. Geophys Res Lett 32(18), L18703

15. Terry JP (2007) Tropical Cyclones: Climatology and Impacts in the South Pacific. Springer, Berlin

16. Palmer E (2007) Out of Sunda? Provenance of the Jōmon Japanese. Nichibunken Japan Rev 19:47-75

17. Carlqvist A (2010) The land-pulling myth and some aspects of historic reality. Japanese J Relig Stud 37(2):185-222

18. Nunn PD (2003) Fished up or thrown down: the geography of Pacific Island origin myths. Ann Assoc Am Geogr 93(2):350-364

19. Gaur A (2007) Evidence of shoreline shift on the Northern Saurashtra coast: study based on the submerged temple complex at Pindara. Curr Sci 92 (6):733-735

20. Gaur A, Vora K (1999) Ancient shorelines of Gujarat, India, during the Indus civilization (late mid-holocene): a study based on archaeological evidences. Curr Sci 77:180-185

21. Iyengar R, Radhakrishna B (2005) Evolution of the Western coastline of India and the probable location of Dwaraka of Krsna: geological perspectives. J Geol Soc India 66(3):285-292

22. Tripati S, Gaur A, Gudigar P (1996) Marine archaeological explorations in the Kaveripoompattinam regions: fresh light on the structural remains. Man Environ 21(1):86-90

23. Gaur A (1997) Underwater exploration off poompuhar and possible causes of its submergence. Puratattva 26:84-90

24. Rajani M, Kasturirangan K (2013) Sea-level changes and its impact on coastal archaeological monuments: seven Pagodas of Mahabalipuram, a case study. J Indian Soc Remote Sensing 41(2):461-468

25. Shulman D (1988) The Tamil flood myths and the Cankam Legend. In: Dundas A (ed) The Flood Myth. University of California Press, Berkeley

26. Ramaswamy S (2004) The Lost Land of Lemuria: Fabulous Geographies. University of California Press, Catastrophic Histories, Berkeley

27. Chandrasekharam D (2007) Geo-Mythology of India. In: Piccardi L, Masse WB (eds) Myth and Geology. Geological Society of London, London

28. Bahuguna A, Nayak S, Deshmukh B (2003) IRS views the adams bridge (bridging India and Sri Lanka). J Indian Soc Remote Sensing 31(4):237-239

29. Blake BJ (1991) Woiwurrung, the Melbourne Language. In: Dixon RMW Blake BJ (eds) The Handbook of Australian Languages. Oxford University Press, Oxford

30. Campbell AH (1967) Aboriginal traditions and the prehistory of Australia. Mankind 6(10):476-481

31. Dixon RM (1980) The Languages of Australia. Cambridge University Press, Cambridge

32. Mulvaney DJ, Kamminga J (1999) Prehistory of Australia. Allen and Unwin, Crows Nest, Australia

33. Moore GF (1884) Diary of Ten Years Eventful Life of an Early Settler in Western Australia; and also A Descriptive Vocabulary of the Language of the Aborigines. Walbrook (facsimile edition 1978 by University of Western Australia Press), London

34. Dixon RM (1972) The Dyirbal Language of North Queensland. Cambridge University Press, Cambridge
35. Carson MT, Hung HC, Summerhayes G, Bellwood P (2013) The pottery trail from Southeast Asia to the Pacific. J Island Coastal Archaeol 8:17-36

36. Lal KK, Nunn PD (2011) Holocene sea levels and coastal change, south-west Viti Levu Island, Fiji. Aust Geogr 42(1):41-51

37. Beckwith MW (1977) Hawaiian Mythology. University of Hawai'i Press, Honolulu

38. Albert S, Udy J, Baines G, McDougall D (2007) Dramatic tectonic uplift of fringing reefs on ranongga is Solomon Islands. Coral Reefs 26(4):983-983

39. Nunn PD (1995) Holocene tectonic histories for five islands in the south-central lau group, south Pacific. The Holocene 5(2):160-171

40. Nunn PD (2004) Myths and the formation of Niue island, central South Pacific. J Pac Hist 39(1):99-108

41. Nunn PD (2009) Vanished Islands and hidden continents of the Pacific University of Hawai'i Press, Honolulu

42. Thomson B (1902) Savage Island: an account of a sojourn in Niue and Tonga. John Murray, London

43. Nunn PD, Baniala M, Harrison M, Geraghty P (2006) Vanished islands in Vanuatu: new research and a preliminary geohazard assessment. J R Soc N Z 36(1):37-50

44. Nunn PD, Heorake T, Tegu E, Oloni B, Simeon K, Wini L, Usuramo S, Geraghty P (2006) Geohazards revealed by myths in the Pacific: a study of islands that have disappeared in Solomon Islands. South Pacific Stud 27:37-49

45. St Johnston TR (1921) The Islanders of the Pacific, or The Children of the Sun. Fisher Unwin, London

46. Filmer P, McNutt M, Webb H, Dixon D (1994) Volcanism and archipelagic aprons in the Marquesas and Hawaiian Islands. Mar Geophys Res 16(5):385-406

47. Kaehlig C-B, Wight A, Smith C (2013) Volcanoes of Indonesia: Creators and Destroyers. Editions Didier Millet, Singapore

48. Englert S (1972) Island at the Centre of the World: New Light on Easter Island. Robert Hale, London

49. Carson MT, Athens JS (2007) Integration of coastal geomorphology, mythology, and archaeological evidence at Kualoa beach, windward O'ahu, Hawaiian Islands. J Island Coastal Archaeol 2(1):24-43

50. Nunn PD, Pastorizo MR (2007) Geological histories and geohazard potentia of Pacific Islands illuminated by myths. In: Piccardi L, Masse WB (eds) Myth and Geology. Geological Society of London, London

51. Geraghty P (1993) Pulotu, Polynesian homeland. J Polyn Soc 102(4):343-384

52. Phinney EJ, Mann P, Coffin MF, Shipley TH (1999) Sequence stratigraphy, structure, and tectonic history of the southwestern Ontong Java plateau adjacent to the North Solomon Trench and Solomon Islands arc. J Geophys Res Solid Earth (1978-2012) 104(B9):20449-20466

53. Phinney EJ, Mann P, Coffin MF, Shipley TH (2004) Sequence stratigraphy, structural style, and age of deformation of the Malaita accretionary prism (Solomon arc-Ontong Java Plateau convergent zone). Tectonophysics 389 (3):221-246

54. Fox CE (1925) The Threshold of the Pacific. Knopf, New York

55. Woodford CM (1926) Notes on the Solomon Islands. Geogr J 68(6):481-487

56. Nunn PD (1999) Early human settlement and the possibility of contemporaneous volcanism, western Kadavu, Fiji. Domodomo (Schol J Fiji Museum) 12:36-49

57. Cronin SJ, Ferland MA, Terry JP (2004) Nabukelevu volcano (Mt. Washington), Kadavu - a source of hitherto unknown volcanic hazard in Fiji. J Volcanol Geotherm Res 131(3):371-396

58. Nichol R (1992) The eruption history of Rangitoto: reappraisal of a small New Zealand myth. J R Soc N Z 22(3):159-180

59. Etienne S, Terry JP (2012) Coral boulders, gravel tongues and sand sheets: features of coastal accretion and sediment nourishment by Cyclone Tomas (march 2010) on Taveuni Island, Fiji. Geomorphology 175:54-65

60. Tanaka H, Tinh NX, Umeda M, Hirao R, Pradjoko E, Mano A, Udo K (2012) Coastal and estuarine morphology changes induced by the 2011 Great East Japan Earthquake Tsunami. Coast Eng J 54(01):1250010

61. Brunsden D, Thornes JB (1979) Landscape sensitivity and change. Trans Inst Br Geogr 4:463-484

62. Karim MF, Mimura N (2008) Impacts of climate change and sea-level rise on cyclonic storm surge floods in Bangladesh. Glob Environ Chang 18(3):490-500

63. Field CB, Barros V, Stocker TF, Dahe Q (2012) Managing the Risks of Extreme Events and Disasters to Advance Climate Change Adaptation: Special Report of the Intergovernmental Panel on Climate Change. Cambridge University Press, Cambridge 
64. Tripati S (2009) Coastal structural remains on the east coast of India: evidence of maritime activities and their significances. In: Reddy PC (ed) Saundaryashri: Studies of Indian History, Archaeology, Literature and Philosophy (Festschrift to Professor A. Sundara). Sharada Publishing House, New Delhi

65. Kench PS, Smithers SG, McLean RF, Nichol SL (2009) Holocene reef growth in the Maldives: evidence of a mid-holocene sea-level highstand in the central Indian Ocean. Geology 37(5):455-458

66. Ranasinghe PN, Ortiz JD, Moore AL, McAdoo B, Wells N, Siriwardana CHER, Wijesundara DTDS (2013) Mid-Late Holocene coastal environmental changes in southeastern Sri Lanka: New evidence for sea level variations in southern Bay of Bengal. Quat Int 298:20-36

67. Rao S (1990) Excavation of the legendary city of Dvaraka in the Arabian Sea. Marine Archaeol 1:59-98

68. Dura T, Rubin CM, Kelsey HM, Horton BP, Hawkes A, Vane CH, Daryono M, Pre CG, Ladinsky T, Bradley S (2011) Stratigraphic record of holocene coseismic subsidence, Padang, West Sumatra. J Geophys Res Solid Earth B11306

69. Niwa Y, Sugai T, Yasue KI (2012) Activity of the Yoro fault system determined from coseismic subsidence events recorded in the Holocene delta sequence of the Nobi plain, central Japan. Bull Seismol Soc Am 102 (3):1120-1134

70. Soter S, Katsonopoulou D (2011) Submergence and uplift of settlements in the area of Helike, Greece, from the Early Bronze Age to late antiquity. Geoarchaeology 26(4):584-610

71. Oliveira C (2008) Review of the 1755 Lisbon earthquake based on recent analyses of historical observations. Historical Seismol 2:261-300

72. Greene HG, Wong FL (1988) Geology and Offshore Resources of Pacific Island Arcs - Vanuatu Region. Circum-Pacific Council for Energy and Mineral Resources, Houston

73. Leonard LJ, Hyndman RD, Mazzotti S (2004) Coseismic subsidence in the 1700 great cascadia earthquake: coastal estimates versus elastic dislocation models. Geol Soc Am Bull 116(5-6):655-670

74. Rajendran C, Rajendran K, Anu R, Earnest A, Machado T, Mohan P, Freymueller J (2007) Crustal deformation and seismic history associated with the 2004 Indian Ocean earthquake: a perspective from the Andaman-Nicobar Islands. Bull Seismol Soc Am 97(1A):S174-S191

75. Mercer J, Dominey-Howes D, Kelman I, Lloyd K (2007) The potential for combining indigenous and western knowledge in reducing vulnerability to environmental hazards in small island developing states. Environ Hazards 7 (4):245-256

76. Mercer J, Kelman I, Taranis L, Suchet-Pearson S (2010) Framework for integrating indigenous and scientific knowledge for disaster risk reduction. Disasters 34(1):214-239

77. Cashman KV, Cronin SJ (2008) Welcoming a monster to the world: myths, oral tradition, and modern societal response to volcanic disasters. J Volcanol Geotherm Res 176(3):407-418

78. Cronin SJ, Cashman KV (2008) Volcanic Oral Traditions in Hazard Assessment and Mitigation. In: Gratton J, Torrence R (eds) Living Under the Shadow: Cultural Impacts of Volcanic Eruption. Left Coast Press, Oakland, California

79. Heyd T, Brooks N (2009) Exploring Cultural Dimensions of Adaptation to Climate Change. In: Adger WN, Lorenzoni I, O'Brien K (eds) Adapting to Climate Change: Thresholds, Values, Governance. Cambridge University Press, Cambridge

80. De Bélizal É, Lavigne F, Gaillard JC, Grancher D, Pratomo I, Komorowski J-C (2012) The 2007 eruption of Kelut volcano (East Java, Indonesia): phenomenology, crisis management and social response. Geomorphology 136(1):165-175

81. Bankoff G (2003) Cultures of Disaster: Society and Natural Hazard in the Philippines. Routledge, London

82. Rodolfo KS, Umbal JV (2008) A prehistoric lahar-dammed lake and eruption of Mount Pinatubo described in a Philippine aborigine legend. J Volcanol Geotherm Res 176(3):432-437
83. Church JA, Clark PU, Cazenave A, Gregory JM, Jevrejeva S, Levermann A, Merrifield MA, Milne GA, Nerem RS, Nunn PD, Payne AJ, Pfeffer WT, Stammer D, Unnikrishnan AS Sea Level Change. In: Stocker TF, Qin D, Plattner G-K, Tignor M, Allen SK, Boschung J, Nauels A, Xia Y, Bex V, Midgley PM (eds) Climate Change 2013: The Physical Science Basis. Contribution of Working Group I to the Fifth Assessment Report of the Intergovernmental Panel on Climate Change (IPCC). Cambridge University Press, Cambridge, in press

84. Lasco R, Kameyama Y, Jiang K, Peñalba L, Pulhin J, Shukla P, Subramanian SM (2014) Climate and Sustainability. In: Manton MJ, Stevenson LA (eds) Climate in Asia and the Pacific. Springer, Dordrecht

85. Nunn PD (2013) The end of the Pacific? Effects of sea level rise on Pacific Island livelihoods. Singap J Trop Geogr 34(2):143-171

doi:10.1186/2196-4092-1-3

Cite this article as: Nunn: Geohazards and myths: ancient memories of rapid coastal change in the Asia-Pacific region and their value to future adaptation. Geoscience Letters 2014 1:3.

\section{Submit your manuscript to a SpringerOpen ${ }^{\odot}$ journal and benefit from:}

- Convenient online submission

- Rigorous peer review

- Immediate publication on acceptance

- Open access: articles freely available online

- High visibility within the field

- Retaining the copyright to your article

Submit your next manuscript at $>$ springeropen.com 